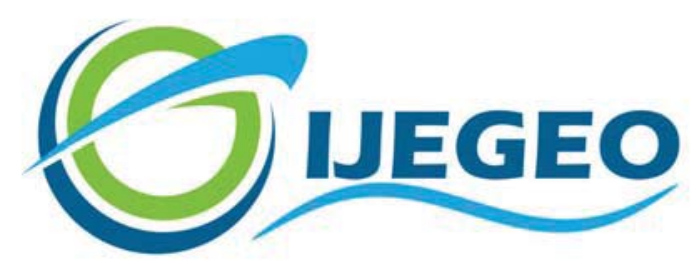

International Journal of Environment and Geoinformatics (IJEGEO) is an international, multidisciplinary, peer reviewed, open access journal.

\title{
The Use of Object-Based Image Analysis for Monitoring 2021 Marine Mucilage Bloom in the Sea of Marmara
}

\section{Taskin KAVZOGLU, Hasan TONBUL, Ismail COLKESEN, Umut Gunes SEFERCIK}

\author{
Chief in Editor \\ Prof. Dr. Cem Gazioğlu \\ Co-Editors \\ Prof. Dr. Dursun Zafer Şeker, Prof. Dr. Şinasi Kaya, \\ Prof. Dr. Ayșegül Tanık and Assist. Prof. Dr. Volkan Demir
}

Editorial Committee (December 2021)

\begin{abstract}
Assoc. Prof. Dr. Abdullah Aksu (TR), Assit. Prof. Dr. Uğur Algancı (TR), Prof. Dr. Bedri Alpar (TR), Assoc. Prof. Dr. Aslı Aslan (US), Prof. Dr. Levent Bat (TR), Prof. Dr. Paul Bates (UK), İrşad Bayırhan (TR), Prof. Dr. Bülent Bayram (TR), Prof. Dr. Luis M. Botana (ES), Prof. Dr. Nuray Çağlar (TR), Prof. Dr. Sukanta Dash (IN), Dr. Soofia T. Elias (UK), Prof. Dr. A. Evren Erginal (TR), Assoc. Prof. Dr. Cüneyt Erenoğlu (TR), Dr. Dieter Fritsch (DE), Prof. Dr. Çiğdem Göksel (TR), Prof.Dr. Lena Halounova (CZ), Prof. Dr. Manik Kalubarme (IN), Dr. Hakan Kaya (TR), Assist. Prof. Dr. Serkan Kükrer (TR), Assoc. Prof. Dr. Maged Marghany (MY), Prof. Dr. Michael Meadows (ZA), Prof. Dr. Nebiye Musaoğlu (TR), Prof. Dr. Masafumi Nakagawa (JP), Prof. Dr. Hasan Özdemir (TR), Prof. Dr. Chryssy Potsiou (GR), Prof. Dr. Erol Sarı (TR), Prof. Dr. Maria Paradiso (IT), Prof. Dr. Petros Patias (GR), Prof. Dr. Elif Sertel (TR), Prof. Dr. Nüket Sivri (TR), Prof. Dr. Füsun Balık Şanlı (TR), Prof. Dr. Uğur Şanlı (TR), Duygu Ülker (TR), Prof. Dr. Seyfettin Taş (TR), Assoc. Prof. Dr. Ömer Suat Taşkın (TR), Assist. Prof. Dr. Tuba Ünsal (TR), Dr. Manousos Valyrakis (UK), Dr. İnese Varna (LV), Dr. Petra Visser (NL), Prof. Dr. Selma Ünlü (TR), Assoc. Prof. Dr. Oral Yağcı (TR), Prof. Dr. Murat Yakar (TR), Assoc. Prof. Dr. İ. Noyan Yılmaz (AU); Assit. Prof. Dr. Sibel Zeki (TR)
\end{abstract}




\title{
Research Article
}

\section{The Use of Object-Based Image Analysis for Monitoring 2021 Marine Mucilage Bloom in the Sea of Marmara}

\author{
Taskin Kavzoglu, (iD) Hasan Tonbul, (i) Ismail Colkesen, (D) Umut Gunes Sefercik (iD)
}

Gebze Technical University, Department of Geomatics Engineering, Gebze, Kocaeli, Turkey

* Corresponding author: T. Kavzoglu

Received:01.08.2021

E-mail: kavzoglu@gtu.edu.tr

Accepted: 03.09.202

How to cite: Kavzoglu, et al., (2021). The Use of Object-Based Image Analysis for Monitoring 2021 Marine Mucilage Bloom in the Sea of Marmara, International Journal of Environment and Geoinformatics (IJEGEO), 8(4):529-536. DOI: 10.30897/ijegeo.990875

\begin{abstract}
Global warming threatens ecosystems through rising temperatures, increasing sea levels, drought, and extreme weather conditions. The natural balance of seas and oceans is also at stake with recent outbreaks of mucilage events all over the world. The mucilage phenomenon, which has been frequently observed in the Adriatic and Tyrrhenian seas, has taken place the second time in the Sea of Marmara in Spring 2021. The Sea of Marmara dividing the Asian and European parts of Turkey is an important inland sea with heavy maritime traffic, hosting many industrial zones and surrounded by highly populated cities. This study aims to determine the mucilage formations that were observed intensely all around the Sea of Marmara, focusing on the coasts of Istanbul, Kocaeli, Yalova, and Bursa through classifying Sentinel-2A images dated 19 and 24 May 2021, when the peak period of mucilage bloom, using a new paradigm of object-based image analysis (OBIA) approach. To create representative and homogenous image objects, multi-resolution segmentation was applied, and its result was inputted into a classification process using Random Forest (RF) classifier to generate thematic maps. The produced results were compared with pixel-based classification and a high correlation was estimated. Objectbased classification was found effective for the determination of mucilage-covered areas (>90\% overall accuracy) for both considered dates. More specifically, areas covered with mucilage aggregates were computed as $56.15 \mathrm{~km}^{2}$ and $67.51 \mathrm{~km}^{2}$ for $19 \mathrm{May}$ and 24 May 2021, respectively, indicating rapid growth in only 5-day period. The resulting thematic maps revealed that mucilage was heavily distributed in the gulfs of Gemlik and Izmit and along the coasts of Darica, Tuzla and Pendik.
\end{abstract}

Keywords: Mucilage, OBIA, Random Forest, Segmentation, Sentinel-2A

\section{Introduction}

Marine mucilage, also known as "sea snot" or "sea saliva", is defined as a set of gelatinous aggregates formed on the sea surface, whose length can range from $0.5 \mathrm{~cm}$ to few kilometers. Mucilage is an organic material that phytoplankton, which is an important part of biological production in the marine environment, secretes into the water by excessive proliferation, mainly caused by environmental factors. It contains bacterial and viral content, and poses a serious problem, especially for the industrial fishing and tourism sectors, if it is effective for a long time (Azam et al., 1999; Balkıs-Ozdelıce et al., 2021; Savun-Hekimoğlu and Gazioğlu, 2021). It is a serious environmental problem with adverse effects on the eggs and larval forms of many fish living near the seabed (Rinaldi et al., 1995). It is regarded as a natural phenomenon, but a great uncertainty remains about its origins (Cozzi et al., 2004). Sudden temperature changes, wind speed, and excessive precipitation are all effective in the continuity of mucilage cases (Yentur et al., 2013). Until now, many scientific studies have been conducted in the Adriatic and Tyrrhenian seas, where mucilage is the most effective for the last two hundred years (Funari and Ade, 1999; Giani et al., 2005; Kraus and Supić, 2015).
Analysis of meteorological data from the period 18652002 showed a significant correlation between temperature anomalies and the presence of mucilages (Deserti et al., 2005). Considering hydrological conditions, researchers (e.g., Buzzelli et al., 1997; Urbani et al., 2005) reported that mucilage formation is usually formed under oligotrophic conditions. GotsisSkretas (1995) reports 23 mucilage incidents regarding the coasts of Greece and states that mucilage, which usually occurs in the summer season, cannot be directly associated with eutrophication, and therefore a complex relationship exists. According to Mecozzi et al. (2005), "the formation of mucilages is an alteration of the natural humification process that occurs when the organic matter degradation phase becomes slower than the synthesis phase. This alteration can be produced by the synergic action of several hydrological, biological, and climatic conditions in the water column".

Formation of marine mucilage in the seas and oceans is not a new phenomenon since it has been first observed off the coast of Italy in 1729 (Bianchi, 1746), indicating that marine pollution cannot be the only reason (Vollenwider and Rinaldi, 1995). Irregularities in both frequency and intensity have been reported in mucilage events (Rinaldi et al., 1995; Gigliotti, 2013). All these considerations reveal the difficulty of determining the 
time, quantity, and distribution of mucilage events. These events observed from the 1800s to the present day in and around the Mediterranean Sea are chronologically reported by Danovaro et al. (2009). In the Sea of Marmara, which is the transition zone of waters with different heat and salinity rates from the Mediterranean Sea and the Black Sea, the first mucilage formation was observed in the summer of 2007 and the average temperature of mucilage areas was measured as $18.4 \pm 1.0^{\circ} \mathrm{C}$ (Aktan et al., 2008, Tas et al., 2020). It should be mentioned that mucilage formations were also observed in the Dardanelles Strait between October 2008 and August 2009 (Yentur et al., 2013). Tüfekçi et al. (2010) concluded after in-situ measurements (October 2007-February 2008) that phytoplankton abundance and environmental conditions during mucilage formation in the Marmara Sea and concluded that several phytoplankton species played a role in mucilage formation. In addition, a low nitrogen-phosphorus ratio was noted in water samples taken from the Gulf of Izmit. The differentiation in this ratio in seawater is also considered as a cause of mucilage formation (Tüfekçi et al., 2010; Tas et al., 2020). The last mucilage presence before the bloom in Spring 2021 was reported by Özalp (2021) in December 2020 in the Dardanelles Strait.

Remote sensing technologies are an important data source for monitoring and detecting natural and artificial changes related to the time occurring on earth. Detection and periodic monitoring of changes caused by climate change caused by global warming are also intensely studied using remotely sensed data. Among these studies, algal blooms and water quality analyses are the most important ones. Monitoring environmental disasters in the oceans and seas and oil spills left from the ships can also be effectively monitored with remote sensing technology. However, a limited number of studies (e.g., Zambianchi, 1992; Tassan, 1993; Berthon and Zibordi, 2000; Gigliotti, 2013) exist in the literature for the monitoring of the formation and movements of mucilages in the seas (Acar et al., 2021).

Recently, a novel paradigm, namely object-based image analysis (OBIA) also referred Geospatial Object-based Image Analysis (GEOBIA) has gained rapid popularity to classify or map high-resolution remotely sensed imagery into meaningful objects (Blaschke 2010; Blaschke et al. 2014). OBIA, as an alternative to the pixel-based approach, provides reasonable and automated techniques for the analysis of high-resolution images based on their intrinsic features (spatial, spectral, textural, and topological features) (Lang, 2008; Kavzoglu et al., 2017; Kavzoglu and Tonbul, 2018). By taking highly advantage of this approach, a methodological framework can be provided for machinebased interpretation of complex classes defined by structural and hierarchical characteristics (Hay et al., 2003). Essentially, OBIA tries to mimic the human interpretation of remotely sensed images as efficiently as possible through computer-based procedures (Castilla and Hay, 2008). Thus, it has the potential to handle more complex image analysis tasks.
The objective of this study is to map the surface mucilage formations in the Sea of Marmara using multitemporal satellite images through object-based image classification employing the random forest (RF) algorithm, which is a popular machine learning classifier. For this purpose, multi-temporal Sentinel-2A satellite images were used to determine the mucilage aggregates that occurred in the Sea of Marmara in the 2021 bloom period (March-July 2021).

\section{Study Area and Datasets}

For this study, an area of approximately 4,000 km2 covering the eastern, northeastern, and southeastern parts of the Sea of Marmara, where the movements of surface mucilage formations were intensively observed, was determined as the study area (Figure 1). The Sea of Marmara is an inland sea with an area of approximately $11,000 \mathrm{~km}^{2}$, separating Asian and European parts of Turkey through Bosporus Strait. The cities located in the Marmara region contribute significantly to the country's economy in industrial, trade, tourism, and agricultural activities. The Marmara region is also the most industrialized and densely populated region of Turkey and is affected by many polluting sources in terms of water and air pollution.

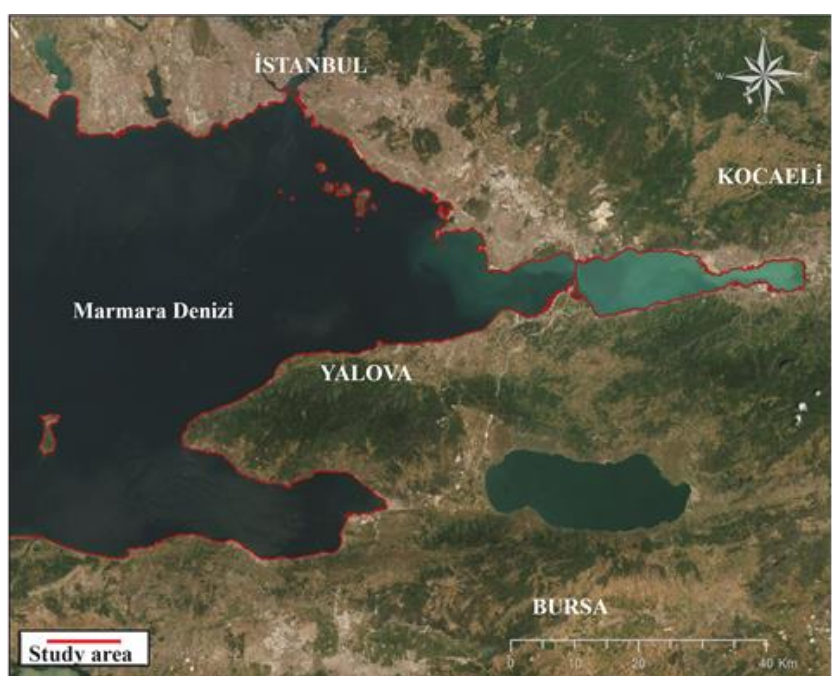

Fig. 1. The location of the study area.

Within the scope of this study, Sentinel-2A data provided by the ESA space missions were utilized for multi-temporal monitoring, detection, and mapping of mucilage formations. Sentinel-2A satellite having a multispectral instrument provides 13 spectral band images with spatial resolutions at $10 \mathrm{~m}, 20 \mathrm{~m}$, and $60 \mathrm{~m}$. In addition to its spatial and spectral properties, 5-day revisit frequency has revealed the use of Sentinel-2 images as the basic data set in many scientific studies. Before the preprocessing, the three bands at $60 \mathrm{~m}$ spatial resolution were excluded from the data set as they were designated for representing atmospheric aerosol and cirrus cloud properties. The processing level of the Sentinel-2A image used in the study is at Level-2A product (BOA reflectance image) and is defined in the WGS84 datum in the UTM projection system. 


\section{Methodology \\ Data Acquisition and Pre-Processing}

In this study, multi-temporal cloud-free Sentinel-2A imagery covering the study area was used to determine spatial distributions of mucilage formations and to map their temporal changes. In this context, Sentinel-2A scenes acquired on 19 and 24 May 2021 were retrieved from the ESA Copernicus Hub portal (https://scihub.copernicus.eu). Since the approximately $4,000 \mathrm{~km} 2$ area selected as a study area does not fit in a single image frame, three image frames were taken at the same date, covering the Sea of Marmara between Istanbul and Yalova, and Kocaeli and Bursa provinces (Table 1). It should be pointed out that Sentinel-2A imagery was mosaicked by ENVI Seamless Mosaic Tool and reprojected to the UTM coordinate system. To minimize the effect of the pixels representing the land and island, the shoreline of the study area was first extracted from the satellite imagery. The land and island pixels were then masked on the mosaicked image.

Table 1. Specifications of the Sentinel 2 images used in this study.

\begin{tabular}{ccc}
\hline Data Source & Acquisition Date & Tile Number \\
\hline \multirow{3}{*}{ Sentinel-2A } & T35TPE \\
\cline { 2 - 3 } & & T35TQF \\
& \multirow{2}{*}{ 24 May 2021 } & T35TPF \\
\hline
\end{tabular}

\section{Image Segmentation}

The primary and crucial step in object-based image analysis (OBIA) is the extraction of relevant image objects by clustering pixels through image segmentation. It is used to divide images into meaningful parts, called segments or image objects, that are homogeneous in terms of their spectral or spatial features (Ryherd and Woodcock 1996). Many segmentation methods and algorithms are available in the literature, which can be broadly classified into four categories as edge-based segmentation, feature space clustering with histograms, region-based segmentation and thresholding (Cheng et al. 2001; Kavzoglu and Tonbul, 2018). Among them, the multi-resolution segmentation, proposed by Baatz and Schäpe (2000), is one of the most popular algorithms within the OBIA community (Luo et al., 2017; Kavzoglu and Tonbul, 2018, Kavzoglu et al., 2018). The multiresolution image segmentation is a bottom-up region merging technique that segments images into groups of pixels and thus produces image objects (Kavzoglu et al., 2016). This algorithm has three main segmentation parameters, namely, scale, shape, and compactness that can be set to determine the degree of homogeneity (Kavzoglu et al., 2017). The quality of segmentation is strongly related to the determination of segmentation parameters determined by the analyst and has a direct impact on the performance of the subsequent classification process (Addink et al., 2007; Kavzoglu 2017; Tonbul and Kavzoglu, 2020). In the literature, there is no universally recognized algorithm or approach for estimating optimum segmentation parameters. On the other hand, many supervised and unsupervised strategies and approaches have been proposed in the literature to estimate optimal segmentation parameters (Espindola et al., 2006; Drăgut et al.,2010; Johnson and Xie, 2011; Drăgut et al.,2014).

\section{Classification}

The OBIA process is based on the principle of using the determined features of the image objects as inputs in the classification process (Jensen, 2005). In this study, random forest $(\mathrm{RF})$, one of the most widely-used machine learning algorithms in the current literature, was employed to classify image segments regarding their spectral and spatial features. The RF algorithm, developed by Breiman (2001), combines multiple decision trees to construct the classification model, and the resulting ensemble model is known as decision forest. The main idea behind the decision forest is to create a diverse decision tree classifier and to make a final prediction for a particular unknown sample by combining their individual predictions. The mentioned process is achieved in two following stages. The first is to use randomly selected samples, collected by means of bootstrap aggregation procedure to construct each member of the forest. For this purpose, two-thirds of the input training samples (referred to in-bag samples) are selected to build the individual tree structure, and onethird of the sample (referred to out-of-bag samples) are employed in the cross-validation process to estimate the prediction performance of the constructed tree model. The second, split conditions are computed for each node in the tree, taking into consideration the predictor variables (Colkesen and Kavzoglu, 2017).

\section{Results}

In order to meet the objectives of this study, three basic processing steps of OBIA, namely segmentation, classification, and accuracy assessment were followed in classifying Sentinel-2A imagery. In the first stage, OBIA based multi-resolution segmentation was implemented for the Sentinel-2A images to split the images into homogeneous image objects or segments. The image segmentation procedure was achieved using eCognition Developer software (v.10.0). To determine the optimal scale value of segmentation, the estimation of scale parameter (ESP-2) tool proposed by Drăgut et al. (2014) was implemented. The tool was developed for the multiresolution image segmentation programmed in the Cognition Network Language environment of eCognition Developer software. In this tool, automatic image segmentation is performed according to the increment amount determined by the user, and variation in heterogeneity is verified by calculating the local variance (LV) based on the corresponding scale. This tool graph indicates the rate of changes in local variance (LV-RoC) and the first peaks of the LV- RoC curve demonstrate appropriate scale values for segmentation (Kavzoglu and Tonbul, 2018; Kavzoglu et al., 2018). For the implementation of ESP-2 default parameter setting (scale increments of 1,10 , and 100, step size level $1=1$ and number of loops $=90$ ) was chosen. For the sake of 
consistency, the shape and compactness parameters of multi-resolution segmentation were kept constant as 0.1 and 0.5 , respectively in all segmentation processes as used in many studies (Dronova et al., 2012; Belgiu et al., 2014; Tonbul et al., 2020). As a result of the analysis of the local variance change rates calculated by the ESP tool, the scale value was calculated as 31 for the image dated May 19, while the scale value was calculated as 24 for the image dated May 24 (Figure 2).

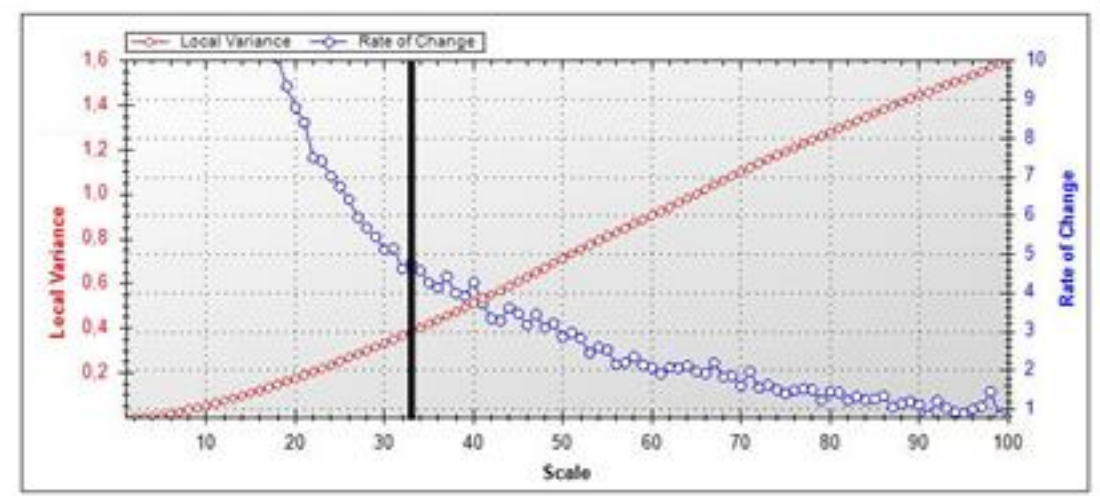

a)

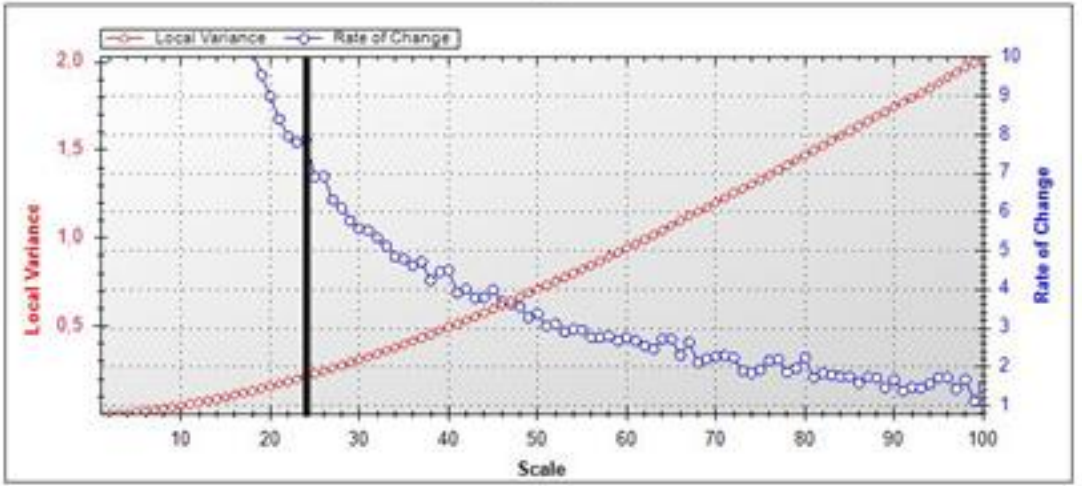

b)

Fig. 2. The analysis result of LV-ROC graph calculated by ESP-2 tool for (a) May-19 image and (b) May-24 image. It should be pointed out that the vertical black line shows the optimal scale parameter for each scene.

As a result of the segmentation processes using optimal scale parameters, totally 84,572 and 131,303 image objects were produced for the May-19 and May-24 images, respectively. It should be noted that all bands of the Sentinel-2A image were evaluated in the multiresolution segmentation process and all image bands were equally weighted as 1 . In order to visually analyze the quality of image segmentation results, two sample subsets belonging to ship and mucilage classes are given in Figure 3. The created image objects accurately overlapped with real earth surface objects for both class segmented images. It should be mentioned that some mucilage image objects were exposed to oversegmentation (Figure 3b).

In the classification stage, sampling areas representing mucilage formations, clear sea, and ship classes in the study area were firstly determined on the RGB image at $10 \mathrm{~m}$ spatial resolution. Then, designated sampling points were associated with the segmented image objects, and then training and test objects were created. In order to apply the classification process to the constructed segments, 52 spectral and spatial object features namely, area-of-pixel values, band ratio values, brightness, standard deviation, mean, maximum, minimum value of spectral bands of Sentinel-2A were calculated for the created image objects. The RF model constructed with 500 trees using the training dataset was applied to the whole segmented image objects having 52 object features, thus thematic maps of the study area were created. At the end of the classification stage, confusion matrices were calculated using validation data sets including 3,300 pixels per class. The estimated individual accuracy measures (F-score, producer's accuracy, and user's accuracy) and overall accuracies of the RF classifier for the thematic maps were presented in Table 2. It is noteworthy to mention that the F-score measure is adapted from the calculation of the harmonic mean of user's and producer's accuracies (Tonbul et al., 2020).

Table 2. Summary of accuracy assessment results for both dates.

\begin{tabular}{|c|c|c|c|c|c|c|}
\hline \multirow[b]{2}{*}{ Class } & \multicolumn{3}{|c|}{ Мay-19 } & \multicolumn{3}{|c|}{ May-24 } \\
\hline & $\begin{array}{c}\text { Producer' } \\
(\%)\end{array}$ & $\begin{array}{c}\text { s User's } \\
(\%)\end{array}$ & $\begin{array}{c}\text { F-score } \\
(\%)\end{array}$ & $\begin{array}{c}\text { Producer's } \\
(\%)\end{array}$ & $\begin{array}{c}\text { User's } \\
(\%)\end{array}$ & $\begin{array}{c}\text { F-score } \\
(\%)\end{array}$ \\
\hline Mucilage & 91.12 & 93.54 & 92.32 & 87.75 & 93.29 & 90.43 \\
\hline Water & 99.71 & 99.77 & 99.74 & 98.97 & 99.97 & 99.47 \\
\hline Ship & 93.17 & 90.80 & 91.97 & 93.44 & 86.78 & 89.98 \\
\hline Overall Ac. & \multicolumn{3}{|c|}{$94.70 \%$} & \multicolumn{3}{|c|}{$93.34 \%$} \\
\hline Kappa & \multicolumn{3}{|c|}{0.92} & \multicolumn{3}{|c|}{0.90} \\
\hline
\end{tabular}




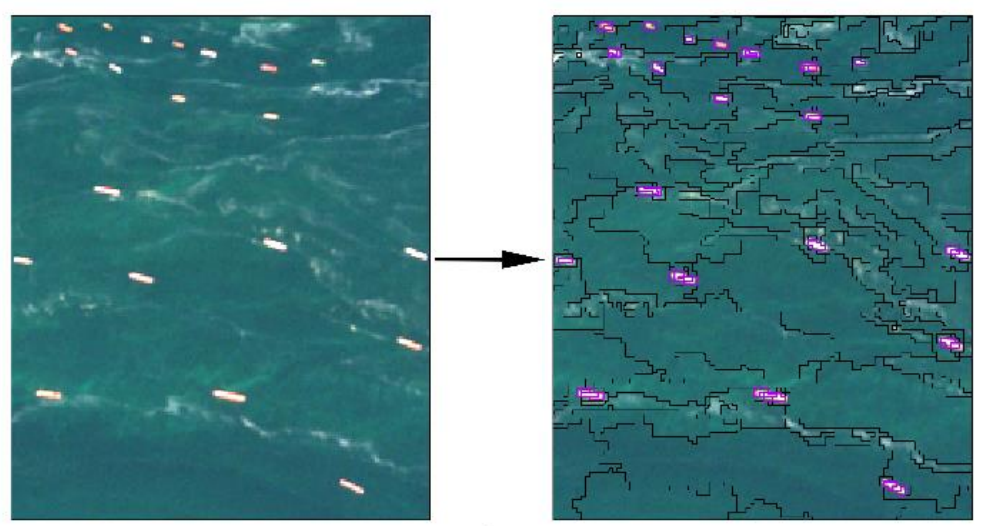

a)
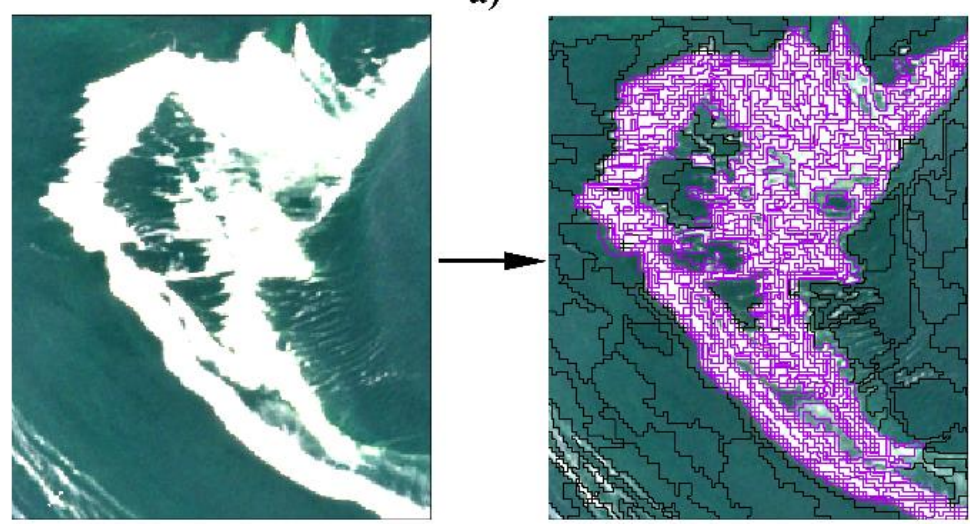

b)

Fig. 3. A subset of segmentation results for ship (a) and mucilage (b) classes.
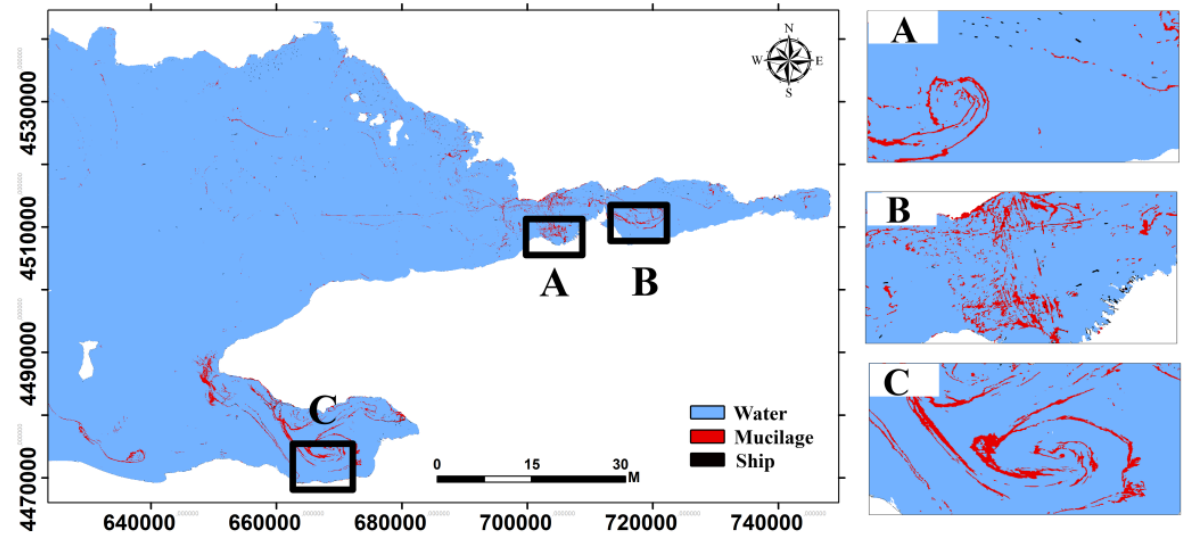

a)
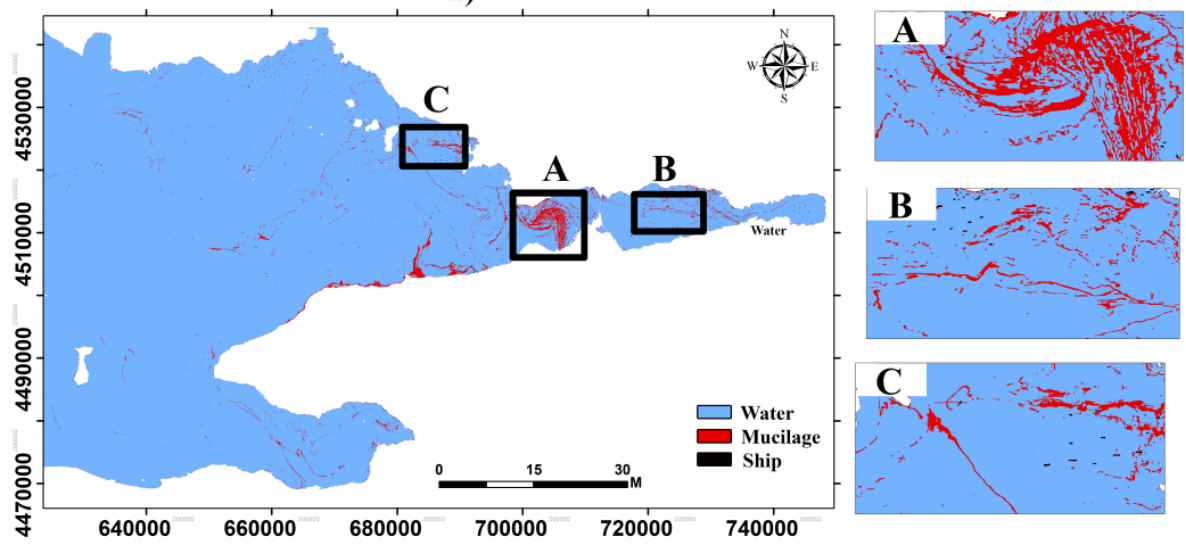

b)

Fig. 4. Thematic maps of the study area for (a) May-19 image and (b) May-24 image. 
As shown in Table 2, the overall accuracies of the classifications were estimated as $94.70 \%$ (Kappa coefficient of 0.92 ) and $93.34 \%$ (Kappa coefficient of 0.90) for May-19 and May-24 images, respectively. Considering the overall accuracies and Kappa coefficients, both images were classified with high classification accuracies (over 90\%). Furthermore, analysis of the individual class accuracies indicated that all classes were classified with more than $87 \%$ accuracy level for both images. When the estimated producer's and user's accuracies were analyzed, the highest accuracies were obtained for the water class with 99.77\% and $99.97 \%$ for May-19 and May-24 images, respectively. Results noticeably indicate that the mucilage class was well separated from the other classes, giving over $90 \%$ F-score accuracies for both images. With the intention of visual evaluation of the classification results, the thematic maps of the study area generated by the RF classifier for both images were presented in Figure 4.

As shown in Figure 4, although the ship and mucilage classes were misclassified in some regions, mucilagecovered areas were clearly identified in both thematic maps. It can be easily observed that mucilage formations were concentrated in the coastal areas of the Armutlu and Mudanya regions of Bursa province. On the other hand, mucilage formations were abundant along the Kadıköy-Tuzla coastline in Istanbul, also up to the Darıca-Körfez coastline in Kocaeli (Figure 4a). When the Figure $4 \mathrm{~b}$ is visually analyzed, it can be seen that mucilage formations were concentrated in the whole of the study area, and significant amounts of mucilage clusters were formed especially in the Çınarcık-Altınova coastal areas of Yalova province and in the region between the Darica-Eskihisar coasts of Kocaeli province. Considering the coasts of Istanbul, it was observed that mucilage aggregates were distributed especially through the Pendik-Tuzla coastline (Figure 4b).

After the classification process, the vectorization process was carried out to determine the acreages of the mucilage-covered areas. Then, the coverage of mucilage formations was estimated as $56.15 \mathrm{~km}^{2}$ on 19 May, covering $1.39 \%$ of the study area (Table 3 ). It was also seen that the acreage of the mucilage aggregates in the study area increased by $20 \%$, reaching $67.51 \mathrm{~km}^{2}$ on May 24, 2021. These results confirm the findings of a recent study based on the mapping of mucilage formation using pixel-based classification carried out by Kavzoglu et al. (2021).

Table 3. Temporal evaluation of mucilage covered areas using object- and pixel-based classification.

\begin{tabular}{ccccc}
\hline \multirow{2}{*}{ Date } & \multicolumn{2}{c}{ Object-based } & \multicolumn{2}{c}{ Pixel-based } \\
\cline { 2 - 5 } & $\begin{array}{c}\text { Areal } \\
\left(\mathbf{k m}^{\mathbf{2}}\right)\end{array}$ & $\begin{array}{c}\text { Ratio } \\
(\boldsymbol{\%})\end{array}$ & $\begin{array}{c}\text { Areal } \\
\left.\mathbf{( k m}^{\mathbf{2}}\right)\end{array}$ & Ratio (\%) \\
\hline 19 May & 56.15 & 1.39 & 57.32 & 1.42 \\
24 May & 67.51 & 1.67 & 70.37 & 1.75 \\
\hline
\end{tabular}

\section{Conclusions}

In this study, areas covered with mucilage aggregates on the sea surface of the eastern part of Sea of Marmara were temporally mapped using Sentinel-2A images. Within this framework, OBIA-based multi-resolution segmentation was applied to the temporal Sentinel-2A data with optimal settings to generate image objects. Subsequently, the images were classified to determine the distribution of mucilages in the Sea of Marmara. The results showed that sea surface mucilage formations were calculated over $90 \%$ accuracies using RF classifier for satellite images dated 14 and 24 May 2021. While the acreages of the mucilage covered area were estimated as $56.15 \mathrm{~km}^{2}$ on 19 May 2021 , and $67.51 \mathrm{~km}^{2}$ on 24 May. The results also revealed that the formation of mucilage increased rapidly within the specific fiveday period. This finding was parallel to the results of previous research conducted by Kavzoglu et al. (2021) on the determination of mucilage-covered areas using pixel-based image classification for the same study site. The differences in mucilage-covered areas were calculated as $1.17 \mathrm{~km}^{2}$ and $2.86 \mathrm{~km}^{2}$, indicating about $2 \%$ and 4\% differences, for May 19 and 24, 2021 images, respectively. One of the most significant findings to emerge from this study is that the remotely sensed time-series data provide a unique opportunity for detecting and monitoring the mucilage formations in marine environments. In particular, the monitoring of mucilage formations in certain periods and the determination of their distribution are of great importance in terms of demonstrating the effectiveness of early warning systems, cleaning studies, and decisionmaking processes. Finally, produced thematic maps can be benefitted together with relevant data (e.g. drainage channels, treatment plants, and potential industrial areas) for estimating possible hotspots and then take precautions for future cases.

\section{References}

Acar, U., Yılmaz, O.S., Çelen, M., Ateş, A.M., Gülgen, F., Balık Şanlı, F. (2021). Determination of Mucilage in The Sea of Marmara Using Remote Sensing Techniques with Google Earth Engine. International Journal of Environment and Geoinformatics, 8(4), 423-434. DOI: 10.30897/ijegeo.957284.

Addink, E.A., de Jong, S.M., Pebesma, E.J. (2007). The importance of scale in object-based mapping of vegetation parameters with hyperspectral imagery. Photogrammetric Engineering and Remote Sensing, 72(8), 905-912.

Aktan, Y., Dede, A., Ciftci, P.S. (2008). Mucilage event associated with diatoms and dinoflagellates in Sea of Marmara, Turkey. Harmful Algae News, 36, 1-3.

Azam, F., Fonda-Umani, S., Funari, E. (1999). Significance of bacteria in the mucilage phenomenon in the northern Adriatic Sea. Ann Ist Super Sanita, 35(3), 411-9. PMID: 10721207.

Baatz, M., Schape, A. (2000). Multiresolution segmentation - An optimization approach for high 
quality multi-scale image segmentation. In: Strobl J. et al. (Eds.), Angewandte Geographische Informationsverarbeitung (pp. 12-23), Herbert Wichmann Verlag.

Balkıs-Ozdelıce, N., Durmuş, T., Balcı, M. (2021). A Preliminary Study on the Intense Pelagic and Benthic Mucilage Phenomenon Observed in the Sea of Marmara, International Journal of Environment and Geoinformatics, 8(4), 414-422.DOI: 10.30897/ijegeo. 954787.

Belgiu, M., Drăguţ, L., Strobl, J. (2014). Quantitative evaluation of variations in rule-based classifications of land cover in urban neighbourhoods using Worldview-2 imagery. ISPRS Journal of Photogrammetry and Remote Sensing, 87, 205-215.

Berthon, J.F., Zibordi, G. (2000). Marine optical measurements of a mucilage event in the northern Adriatic Sea. Limnology and Oceanography, 45(2), 322-327.

Bianchi, G. (1746). Notizie sulla vasta fioritura algale del 1729. Raccolta d'opuscoli scientifici e filologici, 34, 256-257.

Blaschke, T. (2010). Object based image analysis for remote sensing. ISPRS Journal of Photogrammetry and Remote Sensing, 65(1), 2-16.

Blaschke, T., Hay, G.J., Kelly, M., Lang, S., Hofmann, P., Addink, E., Feitosa, R.Q., vander Meer, F., van der Werff, H., van Coillie, F., Tiede, D. (2014). Geographic object-based image analysis towards a new paradigm. ISPRS Journal of Photogrammetry and Remote Sensing, 87, 180-191.

Breiman, L. (2001). Random Forests. Machine Learning, 45(1), 5-32.

Buzzelli, E., Gianna, R., Marchori, E., Bruno, M. (1997). Influence of nutrient factors on production of mucilage by Amphora coffeaeformis var. perpusilla. Continental Shelf Research, 17, 1171-1180.

Castilla, G., Hay, G.J. (2008). Image objects and geographic objects. In: Blaschke T., Lang S., Hay G.J. (Eds.), Object-based image analysis - spatial concepts for knowledge-driven remote sensing applications (pp. 91-110), Springer, Heidelberg, Berlin, New York.

Cheng, H.D., Jiang, X.H., Sun, Y., Wang, J. (2001). Color image segmentation: advances and prospects. Pattern Recognition, 34(12), 2259-2281.

Colkesen, I., Kavzoglu, T. (2017). Ensemble-based canonical correlation forest (CCF) for land use and land cover classification using Sentinel-2 and Landsat OLI imagery. Remote Sensing Letters, 8, 1082-1091.

Cozzi, S., Ivancic, I., Catalano, G., Djakovac, T., Degobbis, D. (2004). Dynamics of the oceanography properties during mucilage appearance in the Northern Adriatic Sea: Analysis of the 1977 event in comparison to earlier events. Journal of Marine Systems, 50, 223-241.

Danovaro, R., Fonda-Umani, S., Pusceddu, A. (2009). Climate change and the potential spreading of marine mucilage and microbial pathogens in the Mediterranean Sea. PloS One. 4(9), e7006.

Deserti, M., Cacciamani, C., Chiggiato, J., Rinaldi, A., Ferrari, C.R. (2005). Relationships between northern
Adriatic Sea mucilage events and climate variability. Science of the Total Environment, 353, 82-88.

Drăgut, L, Tiede, D., Levick, S. (2010). ESP: a tool to estimate scale parameter for multiresolution image segmentation of remotely sensed data. International Journal of Geographical Information Science, 24, 859-871.

Drăgut, L., Csillik, O., Eisank, C., Tiede, D. (2014). Automated parameterisation for multi-scale image segmentation on multiple layers. ISPRS Journal of Photogrammetry and Remote Sensing, 88, 119-127.

Dronova, I., Gong, P., Clinton, N.E., Wang, L., Fu, W., Qi, S., Liu, Y. (2012). Landscape analysis of wetland plant functional types: the effects of image segmentation scale, vegetation classes and classification methods. Remote Sensing of Environment, 127, 357-369.

Espindola, G., Câmara, G., Reis, I., Bins, L., Monteiro, A. (2006). Parameter selection for region-growing image segmentation algorithms using spatial autocorrelation. International Journal of Remote Sensing, 27, 3035-3040.

Funari, E., Ade, P. (1999). Human health implications associated with mucilage in the northern Adriatic Sea. Ann Ist Super Sanita, 35(3), 421-5, PMID:10721208.

Giani, M., Savelli, F., Berto, D., Zangrando, V., Cosović, B., Vojvodić, V. (2005). Temporal dynamics of dissolved and particulate organic carbon in the northern Adriatic Sea in relation to the mucilage events. Science of the Total Environment, 353(1-3), 126-38. PMID: 16289251.

Gigliotti, A. (2013). Extracting temporal and spatial distributions information about marine mucilage phenomenon based on MODIS satellite images; a case study of the Tyrrhenian and the Adriatic Sea, 2010-2012 (MsC thesis). Universidade Nova. Lisboa, Portugal.

Gotsis-Skretas, O. (1995). Mucilage appearances in Greek waters during 1982-1994. Science of the Total Environment, 165, 229-230.

Hay, G.J., Blaschke, T., Marceau, D.J., Bouchard, A. (2003). A comparison of three image object methods for the multiscale analysis of landscape structure. ISPRS Journal of Photogrammetry and Remote Sensing, 57(5-6), 327-345.

Jensen, J.R. (2005). Introductory Digital Image Processing: A Remote Sensing Perspective, 3rd Edition, Upper Saddle River: Prentice-Hall.

Johnson, B., Xie, Z. (2011). Unsupervised image segmentation evaluation and refinement using a multi-scale approach. ISPRS Journal of Photogrammetry and Remote Sensing, 66, 473-483.

Kavzoglu, T. (2017). Object-oriented random forest for high resolution land cover mapping using Quickbird2 imagery. In: Samui P., Roy, S.S., Balas, V.E. (Eds.), Handbook of Neural Computation (pp. 607619), Elsevier.

Kavzoğlu, T., Çölkesen, İ., Sefercik, U.G., Öztürk, M.Y. (2021). Marmara Denizi'ndeki müsilaj oluşumlarının çok zamanlı optik ve termal uydu görüntülerinden makine öğrenme algoritması ile tespiti ve analizi. Harita Dergisi, 166, 1-9. (in Turkish). 
Kavzoglu, T., Erdemir, M.Y., Tonbul, H. (2016). A region-based multi-scale approach for object-based image analysis. International Archives of the Photogrammetry, Remote Sensing \& Spatial Information Sciences, XLI-B7, 241-247.

Kavzoglu, T., Tonbul, H. (2018). An experimental comparison of multi-resolution segmentation, SLIC and K-means clustering for object-based classification of VHR Imagery. International Journal of Remote Sensing, 39(18), 6020-6036.

Kavzoglu, T., Tonbul, H., Yildiz Erdemir, M., Colkesen, I. (2018), Dimensionality reduction and classification of hyperspectral 1mages using object-based image analysis. Journal of the Indian Society of Remote Sensing, 46(8), 1297-1306.

Kavzoglu, T., Yildiz Erdemir, M., Tonbul, H. (2017). Classification of semiurban landscapes from very high-resolution satellite images using a regionalized multiscale segmentation approach. Journal of Applied Remote Sensing, 11(3), 035016.

Kraus, R., Supić, N. (2015). Sea Dynamics impacts on the macroaggregates: A case study of the 1997 mucilage event in the northern Adriatic. Progress in Ocenaography, 138, 249-267.

Lang, S. (2008). Object-based image analysis for remote sensing applications: modeling reality - dealing with complexity. In: Blaschke, T., Lang, S., Hay, G.J. (Eds.), Object-based image analysis - spatial concepts for knowledge-driven remote sensing applications (pp. 3-27), Springer, Heidelberg, Berlin, New York.

Luo, H., Li, D., Liu, C. (2017). Parameter evaluation and optimization for multi-resolution segmentation in object-based shadow detection using very high resolution imagery. Geocarto International, 32(12), 1307-1332.

Mecozzi, M., Pietrantonio, E., Noto, V., Papai, Z. (2005). The humin structure of mucilage aggregates in the Adriatic and Tyrrhenian seas: hypothesis about the reasonable causes of mucilage formation. Marine Chemistry, 95, 255-269.

Özalp, H.B. (2021). First massive mucilage event observed in deep waters of Çanakkale Strait (Dardanelles), Turkey. Journal of the Black Sea/Mediterranean Environment, 27(1), 49-66.

Rinaldi, A., Vollenweider, R.A., Montanari, G., Ferrari, C.R., Ghetti, A. (1995). Mucilages in Italian seas: the Adriatic and Tyrrhenian Seas. 1988-1991, Science of the Total Environment, 165(1-3), 165-183.

Ryherd, S., Woodcock, C. (1996). Combining spectral and texture data in the segmentation of remotely sensed images. Photogrammetric Engineering and Remote Sensing, 62, 181-194.

Savun-Hekimoğlu, B., Gazioğlu, C. (2021). Mucilage problem in the semi-enclosed seas: recent outburst in the Sea of Marmara. International Journal of Environment and Geoinformatics (IJEGEO), 8(4), 402-413. DOI: 10.30897/ijegeo.955739.

Tas, S., Kus, D., Yılmaz, I.N. (2020). Temporal variations in phytoplankton composition in the northeastern Sea of Marmara: potentially toxic species and mucilage event. Mediterranean Marine Science, 21(3), 668-683.
Tassan, S. (1993). An algorithm for the detection of the white-tide ("mucilage") phenomenon in the Adriatic Sea using AVHRR data. Remote Sensing of Environment, 45(1), 29-42.

Tonbul, H., Colkesen, I., Kavzoglu, T. (2020). Classification of poplar trees with object-based ensemble learning algorithms using Sentinel-2A imagery. Journal of Geodetic Science, 10(1), 14-22.

Tonbul, H., Kavzoglu, T. (2020). Semi-automatic building extraction from Worldview-2 imagery using Taguchi optimization. Photogrammetric Engineering and Remote Sensing, 86(9), 547-555.

Tüfekçi, V., Balkıs, N., Beken Polat, Ç., Ediger, D., Mantıkçı, M. (2010). Phytoplankton composition and environmental conditions of a mucilage event in the Sea of Marmara. Turkish Journal of Biology, 34, 199-210.

Urbani, R., Magaletti, E., Sist, P., Cicero, A.M. (2005). Extracellular carbohydrates released by the marine diatoms Cylindrotheca closterium, Thalassiosira pseudonana and Skeletonema costatum: Effect of Pdepletion and growth status. Science of The Total Environment, 353 (1-3), 300-306.

Vollenwider, R.A., Rinaldi, A. (1995). Editorial. The Science of the Total Environment, 165(1995), 5-7.

Yentur, R.E., Buyuates, Y., Ozen, O., Altin, A. (2013). The environmental and socio-economical effects of a biologic problem: Mucilage. Marine Science and Technology Bulletin, 2(2), 13-15.

Zambianchi, E., Calvitti, C., Cecamore, P., D'Amico, F., Ferulano, E., Lanciano, P. (1992). The mucilage phenomenon in the Northern Adriatic Sea, summer 1989: a study carried out with remote sensing techniques. Marine Coastal Eutrophication, 126, 581598. 